\title{
Use of molecular markers as indicators for winter zooplankton grazing on toxic benthic cyanobacteria colonies in an urban Colorado lake
}

\author{
P.J. Oberholster, A.-M. Botha, T.E. Cloete
}

\section{Introduction}

Growth of cyanobacteria occurs year round in some tropical lakes; however, in temperate regions, growth and blooms of cyanobacteria exhibit a characteristic seasonality (Reynolds and Walsby, 1975; Reynolds, 1987; Kalff, 2002). During unfavourable environmental conditions, a number of species persist as resting stages in surface sediments of lakes (Reynolds, 1984; Boström et al., 1989), but colonial Chroococcales genera such as Microcystis do not produce morphologically distinct resting stages, and survive unfavourable conditions as 'dormant' colonies in the surface sediments (Barbiero and Welch, 1992; Lampert, 1995). The ability to switch from photoautotrophy to heterotrophy, based on stored carbohydrate, combined with a reduction in respiration rate and enzymatic activity, is the likely reason why these cyanobacteria can survive in bottom sediments for several months during winter (Reynolds and Walsby, 1975; Latour et al., 2004). Alternatively, in some shallow temperate lakes, small populations of Microcystis and Anabaena may be retained in suspension due to isothermal mixing (Huisman et al., 1999). These overwintering cyanobacteria, whether in sediment or suspension, provide the inoculum for the following season's growth (Reynolds and Rogers, 1976). It explains why, once a water body has become colonized, it will probably continue to experience cyanobacterial blooms as long as eutrophic conditions persist; such a cycle has been described for Microcystis (Reynolds et al., 1981; Verspagen et al., 2005).

Akinetes have been found in drying mud suggesting cyanobacteria can be dispersed by wind as well as water (Anagnostidis and Komare'k, 1990) and there are records of regeneration of Nostoc after 80 years of desiccation, attesting to the longevity of akinetes and spores (May, 1981). Another example of regeneration of cyanobacteria is Nostoc mats, that had dried almost completely under field conditions in $3 \mathrm{~h}$ in Antarctic freshwater ponds; photosynthesis fell to about a fifth of its initial value and ceased entirely after $24 \mathrm{~h}$. Respiration fell almost to zero after $3 \mathrm{~h}$. Rewetting after $48 \mathrm{~h}$ resulted in almost full recovery of both functions within a few minutes (Hawes et al., 1992).

The aims of the present study were to use the $m c y$ gene cluster that encodes microcystin synthetase as a molecular marker to detect the presence of Microcystis populations and potential toxicity during over wintering on the sediment surface of Sheldon Lake, CO, USA. This could potentially provide information on the microcystinproducing genotypes that will form the epilimnetic population in the following summer and, through sampling zooplankton, indicate suitability of overwintering benthic cyanobacteria as food for zooplankton herbivores. For the cyanobacterium, the sediment surface and the water column offer completely different environmental conditions with respect to grazing pressure, light, oxygen and nutrient availabilities. Microcystis are usually organized in colonies, and may produce mucilage layers that make it much more difficult for zooplankton ingestion than in the case of single cells. Failkowsak and Pajdak-Stos (2002) have recently shown that cyanobacteria are able to modify their defense reaction according to grazing risk. Despite these defensive reactions by some phytoplankton, their biomass was shown to decrease significantly during winter periods due to winter grazing by zooplankton (Garnier and Mourelatos, 1991).

The synthesis of toxins by many cyanobacterial blooms can also be viewed as giving a selective advantage, since some zooplanktonic predators are susceptible to these toxins and avoid eating cyanobacteria (Berthon and Brousse, 1995). Microcystin, a hepatotoxin known to be the cause of animal and human death, is produced by the bloom-forming cyanobacterium M. aeruginosa in freshwater bodies worldwide (Carmichael, 1992; Jochimsen et al., 1998). The toxin is produced nonribosomally via a multifunctional enzyme complex, consisting of both peptide synthetase and polyketide synthase modules coded for by the mcy gene cluster (Dittman et al., 1997; Tillett et al., 


\section{Materials and methods}

\subsection{Site description and sampling}

Sheldon Lake, Colorado was excavated in 1874 and is a focal point of the 34.39 ha City Park. In 2002, $41,285.9 \mathrm{~m}^{3}$ of lake sediment were removed to provide additional stormwater retention and to improve the shoreline and water quality of the lake. The lake was drained in November and allowed to dry through December. In early January 2002 when temperatures were freezing, bottom sediment was removed using bulldozers and backhoes. Freezing temperatures are ideal for removing surface sediment. After completion of the project in 2003, Lake Sheldon's water column was mixed using compressed air bubble aerators in order to prevent a repeat of a history of bloom-forming cyanobacteria; the lake was also restocked with largemouth bass (Micropterus salmoides), bluegill sunfish (Lepomis macrochirus), crappie (Pomoxis annularus), channel catfish (Ictalurus punctatus) and rainbow trout (Oncorhynchus mykiss) (Sheldon Lake Drainage Improvement Project, 2002, 2003a, 2003b). A year after the removal of the bottom sediment, macrophytes and submerged vegetation were sparse leading to low numbers of zooplankton, due to poor refuge availability and predation by invertebrates and vertebrates (P.J. Oberholster, unpublished results) (Fig. 1).

\subsection{Sampling of cyanobacteria}

Summer sampling of Microcystis aeruginosa in the water column was done with a Von Dorn bottle during the August cyanobacteria bloom peak. Winter sampling of the bottom was conducted by collection of the first $3 \mathrm{~cm}$ of the top-layer sediment in November and December 2004 at sites A and B on four occasions. The winter sampling was done in shallow areas within the euphotic zone where bloom-forming populations of M. aeruginosa were most abundant during the past summer. Verspagen et al. (2004) had previously shown that the most vital colonies survived in shallow sediments of the euphotic zone in Lake Volkerak. Sediment samples were taken with a Perspex corer $(5 \mathrm{~cm}$ i.d., $10 \mathrm{~cm} \mathrm{~h}$ ) and placed on ice in a darkened cooler during transport to the laboratory. Cyanobacteria

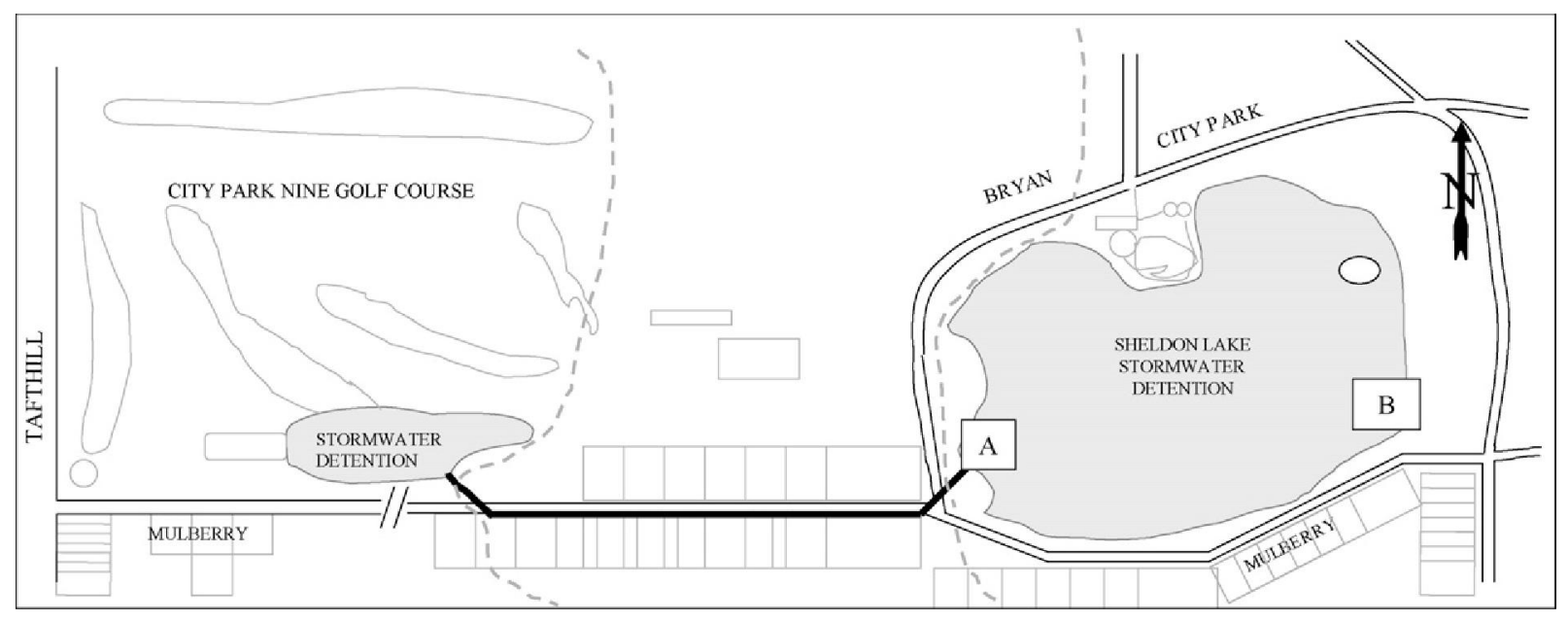

Fig. 1. Map of Sheldon Lake in Ft. Collins, Colorado, USA indicating sampling sites A and B (Sheldon Lake Drainage Improvement Project, 2002). Scale: $10 \mathrm{~m}=5 \mathrm{~mm}$.

colonies were isolated from the sediment within $24 \mathrm{~h}$ by mixing approximately $100 \mathrm{~g}$ of the sediment sample with 
$500 \mathrm{ml}$ distilled water in a glass cylinder followed by fluorescent light illumination. The lower water layers were siphoned off; cells floating on the surface were collected and stored at $4{ }^{\circ} \mathrm{C}$ for no more than 1 week for culture identification. Samples for toxin analysis were processed immediately and stored at $-20{ }^{\circ} \mathrm{C}$ until analyzed. For DNA and RNA isolations, the cells were washed one to three times with distilled water and purified by picking colonies (Kurmayer et al., 2002) before resuspension in distilled water to define volume. Glycerol stocks were prepared from the latter samples and frozen at $-80{ }^{\circ} \mathrm{C}$ for future use. Samples for microscopy were fixed in $2 \%$ formalin (final concentration) (Komárek, 1958). Using a Zeiss inverted light microscope at 1250X magnification, it was established that most microphytobentos consisted of M. aeruginosa (Smith, 1950) and Woronichinia naegeliana (Smith, 1950) colonies. The pooled data from each month, and for the whole sampling period, consisted of the same two cyanobacterial species also observed in the water column during the summer blooms.

Temperatures of surface water and the top centimeter of bottom sediments of the two sampling sites were measured from November to December 2004. Chlorophyll $a$ from water and sediment was extracted from GF filters following lyophilization using $N, N$-dimethyl-formamide for $2 \mathrm{~h}$ at room temperature; absorbances were measured at 647 and $664 \mathrm{~nm}$ and concentrations estimated according to Porra et al. (1989). Transparency (Secchi depth) of the water column was measured with a secchi disc (Wetzel, 1983).

\subsection{Reference cyanobacterial culture}

The axenic $M$. aeruginosa strain PCC 7806 was obtained from the Institute Pasteur (PCC; Paris, France), and cultured in liquid MA medium (Ichimura, 1979) at $25 \pm 2{ }^{\circ} \mathrm{C}$ under continuous illumination of $25 \mu$ mol photons $\mathrm{m}^{-2} \mathrm{~s}^{-1}$. At 21 days, $2 \mathrm{ml}$ of the culture was transferred to a serum vial and lyophilized for $48 \mathrm{~h}$. The sample was then stored under vacuum until DNA was extracted (see below).

\subsection{Sampling of zooplankton}

Crustacean zooplankton was sampled within enclosed areas on four occasions during November and December at sites A and B. Sampling was coincident with the highest concentrations of $>100 \mu \mathrm{m}$ cyanobacteria colonies observed on the bottom sediment. These standardized sampling areas of $0.5 \mathrm{~m}^{2}$ were attained by constructing devices consisting of enclosed tubes, made from water resistant cloth. These devices were sunk to the bottom and sealed against the sediment. Zooplankton was sampled from the enclosed areas after a week using a transparent plastic Schindler-Patalas trap (Schindler, 1969) containing an attached $10 \mu \mathrm{m}$ net. The two hinged doors of the 101 trap swung upward when the trap was lowered between the visible Microcystis colonies on the bottom sediment in the euphotic zone and closed before lifting to the surface. Zooplankton was classified according to Needham and Needham (1962), using a Zeiss inverted light microscope. Identified animals were stored in $5 \%$ ethanol at $4{ }^{\circ} \mathrm{C}$ for DNA extraction and microscopy (Silva and Matsumura-Tundisi, 2005). Zooplankton abundance was determined according to Jeppesen et al. (2004). Intestinal tracts of the Bosmina sp. and Daphnia magna were examined for ingested phytoplankton under a Zeiss inverted light microscope at 1250X magnification.

\subsection{Toxicity measurement}

\subsubsection{Pretreatment and isolation of genomic zooplankton DNA}

After sampling, D. magna and Bosmina sp. contained within the net were washed repeatedly in distilled water to prevent contamination by cyanobacteria present in the water column during sampling. Thereafter, purity of samples was verified by subset sampling using an inverted microscope in order to eliminate potential cyanobacteria contamination before DNA and RNA analysis. The specimens were pipetted into a culture dish and lysed by repetitive pipeting with a micropipette. Whole-organism genomic zooplankton DNA was isolated from liquid samples by using DNAzol ${ }^{\circledR}-$ Genomic DNA isolation reagent (Molecular Research Center, Inc., USA). The DNAzol ${ }^{\circledR}$ procedure is based on the use of a novel Guanidine detergent-lysing solution that hydrolyzes RNA and allows the selective precipitation of DNA from a cell lysate. During the isolation, zooplankton was lysed in DNAzol ${ }^{\circledR}$ and the genomic DNA was precipitated from the lysate with ethanol. Following an ethanol wash, DNA was solubilized in $8 \mathrm{mM} \mathrm{NaOH}$. The procedure was completed in 30 min with a genomic DNA recovery of 70$100 \%$. The isolated DNA was then used for PCR without additional purification (Chomczynski et al., 1997).

For the negative control test organisms, $<24$ h D. magna neonates were obtain from Aquatic Bio Systems, Inc., Fort Collins, CO, USA, and subsequently cultured at $22{ }^{\circ} \mathrm{C}$, under a 16:8 h light:darkness at $10 \mu € \mathrm{~m}^{-2} \mathrm{~s}^{-1}$. The 
culture medium was deionized water, $7.99 \mathrm{pH}$, total hardness of $250 \mathrm{mg} \mathrm{CaCO}_{3} \mathrm{l}^{-1}$ and total alkalinity of $96 \mathrm{mg}$ $\mathrm{CaCO}_{3} \mathrm{l}^{-1}$. Daphnids in the negative control experiment were fed Selenastrum capricornutum, also obtained from Aquatic Bio Systems, Inc., DNA was extracted from the negative control daphnids using a similar approach.

\subsubsection{Pretreatments of environment samples for whole-cell PCR}

For whole-cell PCR, floating cyanobacterial cells that had been isolated from glass cylinders under fluorescent light were washed three times with distilled water, where after colonies were picked (Kurmayer et al., 2002) before analysis. DNA was also extracted from these samples as well as from the reference strain PCC 7806 using the same DNAzol®-Genomic DNA Isolation reagent.

\subsubsection{PCR amplification}

PCR amplification was performed using a Gene-Amp2400 thermocycler (Perkin-Elmer Cetus, Emeryville, CA, USA). The thermal cycling protocol consisted of an initial denaturation step at $94{ }^{\circ} \mathrm{C}$ for 2 min, followed by 35 cycles. Each cycle began with a denaturing step of $10 \mathrm{~s}$ at $93{ }^{\circ} \mathrm{C}$ followed by $20 \mathrm{~s}$ at the annealing temperature of $T_{\mathrm{m}}$ ${ }^{\circ} \mathrm{C}$ for the specific primer pairs (Table 1) and ended with 1 min at $72{ }^{\circ} \mathrm{C}$. When extracted DNA was used, the amplification reactions contained a $10 \mathrm{X}$ amplification buffer with $1.5 \mathrm{mM}$

Table 1

Oligonucleotides used for RT-PCR and PCR analysis

\begin{tabular}{|c|c|c|c|c|}
\hline $\begin{array}{l}\text { Gene region } \\
\text { and primer }\end{array}$ & Sequence & $\mathrm{T}_{\mathrm{m}}\left({ }^{0} \mathrm{C}\right)$ & $\begin{array}{l}\text { Fragment } \\
\text { size }\end{array}$ & Authors \\
\hline \multicolumn{5}{|l|}{ McyA NMT } \\
\hline MSF & 5'-ATCCAGCAGTTGAGCAAGC-3' & 59 & $\sim 1.3 \mathrm{~kb}$ & Tillett et al., 2001 \\
\hline MSR & 5'-TGCAGATAACTCCGCAGTTG-3' & 60 & & \\
\hline \multicolumn{5}{|l|}{ Uma 1} \\
\hline UMF & 5'-CCTATCGTCGTATTTGGAGT-3' & 54 & $\sim 867 \mathrm{bp}$ & \\
\hline UMR & 5'AAGGAATGGACACGATAGGC-3, & 59 & & \\
\hline \multicolumn{5}{|l|}{$M c y B$} \\
\hline Tox 1P & 5'-CGATTGTTACTGATACTCGCC-3' & 57.9 & $\sim 350 \mathrm{bp}$ & Grobbelaar et al., 2004 \\
\hline Tox $1 \mathrm{M}$ & 5'-TAAGCGGGCAGTTCCTGC-3' & 58.2 & & Grobbelaar, 2005 \\
\hline Tox 3P & 5'-GGAGAATCTTTCATGGCAGAC-3' & 62.4 & $\sim 350 \mathrm{bp}$ & \\
\hline Tox $2 \mathrm{M}$ & 5'-CCAATCCCTATCTAACACAGTACCTCGG-3' & 65.1 & & \\
\hline Tox $7 \mathrm{P}$ & 5'-CCTCAGACAATCAACGGTTAG-3' & 53.7 & $\sim 350$ bp & \\
\hline Tox $3 \mathrm{M}$ & 5'-CGTGGATAATAGTACGGGTTTC-3' & 58.4 & & \\
\hline
\end{tabular}

$\mathrm{MgCl}_{2}, 0.2$ mMdNTPs, 20 pmol of each primer and $1 \mathrm{U}$ Taq DNA polymerase, and 3-5 ng purified DNA in a final volume of $50 \mu \mathrm{l}$ (Dittman et al., 1999). Amplification with whole cells started with $6 \mu$ of crude sample, a pretreated subsample with an approximate cell density of $8 \times 10^{6}$ cells ml ${ }^{-1}$, or $0.1 \mu \mathrm{g}$ lyophilized cyanobacterial cells. The sample was added to the reaction mixture $(20-\mu$ l volume $)$ that contained bovine serum albumin $(0.1 \mathrm{mg}$ $\mathrm{ml}^{-1}$ ) or skim milk $\left(0.1-100 \mathrm{mg} \mathrm{ml}^{-1}, \mathrm{w} / \mathrm{v}\right)$, and a $10 \mathrm{x}$ amplification buffer that contained $1.5 \mathrm{mM} \mathrm{MgCl}, 0.2 \mathrm{mM}^{2}$ dNTPs, 20 pmol of each primer, and 0.5 U Taq DNA polymerase (Howitt, 1996) under PCR amplifications conditions identical to those above. The skim milk dosage ranging from 1 to $100 \mathrm{mg} \mathrm{ml}^{-1}$ was determined to be appropriate based on the PCR results.

\subsubsection{RNA extraction and quantitative PCR}

Cells were homogenized using a mortar and pestle and liquid nitrogen; total RNA was extracted using the Qiagen RNAeasy kit (Qiagen Inc., USA) according to the manufacturers' instructions; and using Diethyl pyrocarbonate (DEPC)-treated equipment and solutions. First strand cDNA was synthesized from total RNA using the cDNA synthesis System according to the manufacturers instructions (Roche Molecular Biochemicals, Germany).

Quantitative PCR was performed using $70 \mathrm{ng}$ first strand cDNA from selected total RNA as required, 10 pmol 
forward and reverse primers (Table 1), $3 \mathrm{mM} \mathrm{MgCl}_{2}$ and the LightCycler-FastStart DNA Master SYBR Green 1 Mix (Roche Diagnostics Corporation, Germany) in a $20 \mu \mathrm{l}$ reaction, according to manufacturer's procedures (LightCycler-FastStart DNA Master SYBR Green 1 Manual, Roche Applied Science, Germany). The cycling parameters consisted of 1 cycle at $95^{\circ} \mathrm{C}$ for $10 \mathrm{~min} ; 40$ cycles starting with 1 cycle at $95^{\circ} \mathrm{C}$ for $10 \mathrm{~s}$, primer specific annealing $T^{\circ} \mathrm{C}$ for $5 \mathrm{~s}, 72^{\circ} \mathrm{C}$ for $10 \mathrm{~s}$; followed by the melting curve analysis $\left(95^{\circ} \mathrm{C}\right.$ for $0 \mathrm{~s}, 65^{\circ} \mathrm{C}$ for $15 \mathrm{~s}, 95{ }^{\circ} \mathrm{C}$ for $0 \mathrm{~s}$ ), and cooling $\left(40{ }^{\circ} \mathrm{C}\right.$ for $\left.30 \mathrm{~s}\right)$. A minimum of 7 reactions was done for each fragment analyzed, standard curves were generated using dilution series $(1: 1,1: 10,1: 100,1: 1000)$ and repeated. Results obtained were analyzed using Light-Cycler Software version 3.5 (Roche Applied Science, Germany).

\subsection{Protein phosphatase inhibition and ELISA assays}

Intracellular microcystin content was measured using the colorimetric PP2A inhibition assay (An and Carmichael, 1994). The recombinant catalytic subunit of protein phosphatase 1 as expressed in Escherichia coli was used as the source of PP enzyme (Zhang et al., 1992). This assay has a 50\% inhibitory concentration of $6.72 \mu \mathrm{g}$ $1^{-1}$ or the microcystin-LR standard, using $0.5 \mathrm{mg}$ of PP2A per ml, and a limit of detection of $0.033 \mu \mathrm{g}{ }^{-1}$. Prior to the assay, $1 \mathrm{ml}$ of cells suspended in water (supernatant removed) was freeze-thawed three times and diluted 1:100 to 1:8000. Samples were measured in duplicate in the same assay and also in repeated assays. After adjusting each assay to percentages of protein phosphatase activities, the concentration of microcystin was calculated from an average standard curve of all assays. The PP2A inhibitor, i.e., microcystin content, was calculated for cells per milliliter of sample, resulting in values reported as picomoles of microcystin toxin per cell.

An ELISA assay was conducted with a Quanti ${ }^{\mathrm{TM}}$ Kit for microcystins (EnviroLogix, USA). The microcystin concentration was determined using a standard curve of microcystin-LR (Ueno et al., 1996). The results were obtained by reading the plate on a multiskan ascent (Thermo Labsystems).

\subsection{Data analyses}

For the statistical analysis of the obtained data, results were recorded on standard Excel spreadsheats for data processing, and statistical analysis was conducted using SYSTAT® 7.0.1 (1997).

\section{Results}

Temperatures of water overlying the sediment sample sites as well as the sediment ranged between 4 and $8{ }^{\circ} \mathrm{C}$ from November to mid-December 2004. There was no clear temperature stratification within the water column due to the low water level at both sites. Phytoplankton abundance and composition were high during the summer, but decrease in winter (Fig. 2C and D). Species abundance and community biomass for zooplankton (Fig. 2E) just before ice cover (mid-December to end of January) were low, while phytoplankton chlorophyll $a$ concentration was declining from summer (Fig. 2B). Secchi depth during the sampling dates in summer were generally restricted to the upper $25 \mathrm{~cm}$ of the water column, while in the winter, transparency increased $>40 \mathrm{~cm}$ (Fig. 2A).

The dominant phytoplankton taxa during the sample period, namely Melosira varians and Asterionella formosa, fall within the R-strategy species according to Reynolds (1988). These diatom species are of medium to large size (20$200 \mu \mathrm{m}$ ) and are quite resistant to grazing (Olrik, 1994). During the fall period, a few remaining cladoceran species (D. magna and Bosmina sp.) and rotifers (Keratella sp. and Trichocerca sp.) (Fig. 2E) congregate near the littoral zone sediments and gradually decline in abundance as winter progresses (Lampert and Muck, 1985).

In order to assess the feeding behaviour of cladoceran species, we examined the gut contents of the field $D$. magna specimens microscopically and observed a mixture of phytoplankton with an average contribution of $30 \%$ Microcystis cells; most of these cells were still intact and relatively unharmed. Melosira varians was also found in the gut with the remainder of the contents unidentifiable (not shown).

Amplification products obtained from the M. aeruginosa strains and whole-organism zooplankton DNA sampled in Sheldon Lake provided supporting evidence that the field samples of $M$. aeruginosa and the zooplankton contained the mcy gene cluster present in the M. aeruginosa strain PCC7806 normally associated with toxin production (Dittman et al., 1997; Dittman et al., 2001; Tillett et al., 2001; do Carmo Bittencourt-Oliveira, 2003; Ouahid et al., 2005) (Fig. 3A; Table 2). The cluster included amplification products after amplification with $m c y B-\mathrm{TOX} 1 \mathrm{P} / 1 \mathrm{M}$ ( 350 bp), mcyB-TOX3P/2M ( 350 bp), mcyB-TOX7P/3M ( 350 bp); mcyA-MSR/MSF ( 1.3 kb) and Umal$\mathrm{UMF} / \mathrm{R}(\sim 867 \mathrm{bp})$. The data were further supported by the expression of selected genes in the $m c y$ cluster 


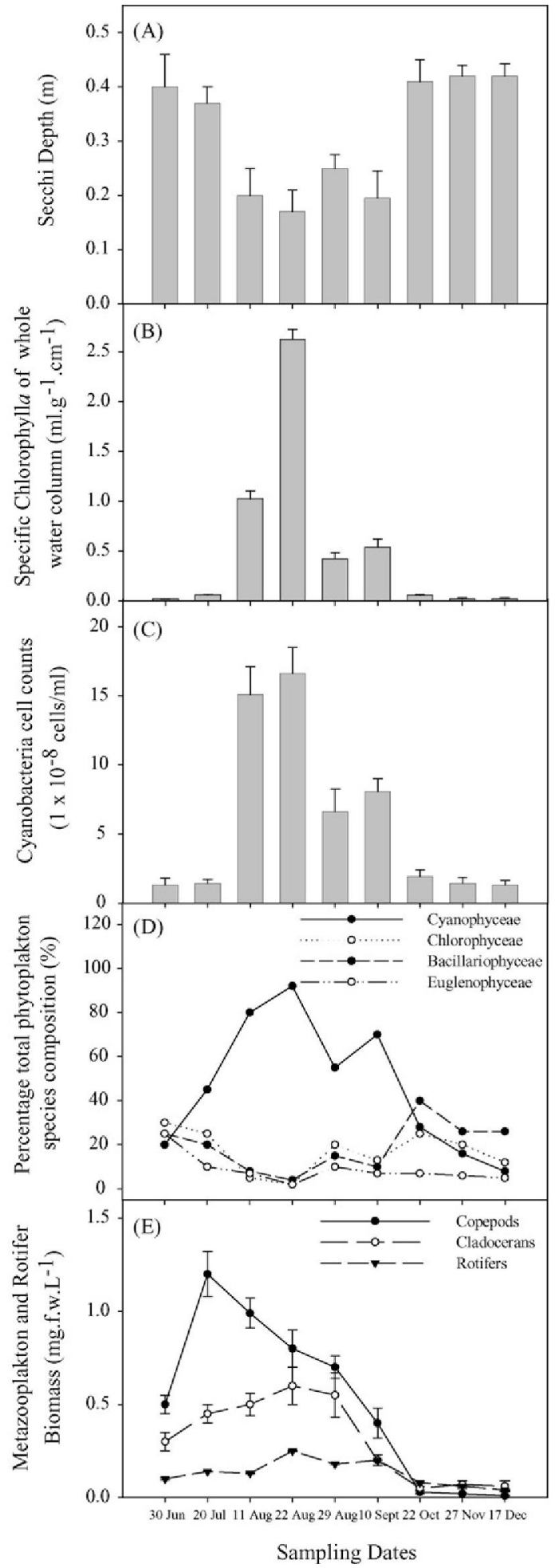

Fig. 2. Average (A) transparency (Secchi depth), (B) chlorophyll $a$, (C) cyanobacteria abundance (cells $\mathrm{ml}^{-1}$ ), (D) phytoplankton composition (relative abundance) and (E) metazooplankton and rotifer biomass during summer and winter 2004, Sheldon Lake, Colorado. Error bars represent standard deviation from the mean value. 
(i.e., $m c y B$-TOX1P/1M, $m c y B$-TOX7P/3M, $m c y B$-TOX3P/2M, $m c y A$-MSR/MSF and Umal -UMF/R using quantitative PCR on total RNA isolated from the field samples (Fig. 3B, Table 2). The toxicity of the field strains was also determined using ELISA and through inhibition of PPA2 and the toxicity levels were comparable to the toxin levels present in the cultured PCC7806 strain (Table 2).

\section{Discussion}

Cyanobacteria, in general, and the rest of the phytoplankton, are important parts of aquatic ecosystems and are grazed upon by many zooplankton taxa such as rotifers, crustaceans and single-celled protozoans. It has been reported that cyanobacterial blooms cause direct decline in numbers of large cladocerans and ostracods (Mills and Wyatt, 1974; Gilbert, 1990; Matveev and Balseiro, 1990; Trabeau et al., 2004), that they can reduce the reproduction rate of rotifers (Arnold, 1971) and both growth and reproduction of cladocerans (Haney, 1987). However, M. aeruginosa is not extensively eaten (Hanazato and Yasuno, 1984; Lampert, 1981a, 1981b, 1987).

Along with most autotrophs, cyanobacteria have evolved strategies to avoid being eaten by facultative heterophs. These include indigestibility or unmanage-ability as food (Richman and Dodson, 1983) or the production of herbivore deterrents (Ostrofsky et al., 1983). The lethality of toxic cyanobacteria to zoo-plankton has been demonstrated in laboratory experiments (Fulton and Paerl, 1987; Rohrlack et al., 2005) and it has been demonstrated to cause the separation of gut cells in daphnids, facilitating the passage of microcystin from the gut into the blood. Previously reported traceable amounts of microcystin were $\sim 2.7 \%$ of the amount offered (Dionisio Pires et al., 2005). While there is a general lack of qualitative and quantitative field data concerning toxic effects of cyanobacteria on zooplankton, it is evident that many forms of zooplankton are significantly affected by them (Vasconcelos, 1990; Lindholm et al., 1992). It has been suggested that the production of toxins by cyanobacteria to reduce grazing pressure by zooplankton may be the main ecological role of these compounds (Lampert, 1981b; Carmichael, 1992; DeMott et al., 1991) and that the toxins produced are also toxic to higher warmblooded animals is likely to be only coincidental, as such a function would be of no evolutionary adaptive advantage to cyanobacteria (Lampert, 1981b). Despite intensive research, the biological function of micro-cystins in M. aeruginosa has not yet been determined. Putative roles for microcystin include feeding deterrence of zooplankton grazers (Jang et al., 2003), siderophoric scavenging of and binding to trace metals such as iron and involvement in group sensing (DeMott et al., 1991; Dittmann et al., 2001; Utkilen and Gjolme, 1995). The current investigation illustrates that benthic Microcystis colonies during winter in or on the bottom sediment of Sheldon Lake are toxic (Table 2), and that the persisting population could preserve the $m c y$ genotype composition from one season to the next depending on inoculation and reinvasion events after severe winters and grazers in the water column (Hansson, 1996, 2000), consistent with previous observations of $M$. aeruginosa reintroduction and bloom formation in the water column from the sediment (Head et al., 1999; Ihle et al., 2005).

Not all zooplankton avoid cyanobacteria as a number of amoebae and ciliates can act as predators (Dryden and Wright, 1987) and the water flea Daphnia pulex has been shown to feed on Aphanizomenon flos-aquae (Holm et al., 1983), while DeBernardi et al. (1981) and DeBernardi and Giussani (1990) observed a strain of Microcystis in single cells or small colonies to be a good food source for Daphnia obtuse and D. hyaline. Field studies of Lake Kasumigaura in Japan have shown that Microcystis blooms can not only be degraded by the rotifer Philodina and the oligochaete Aelosoma (Inamori et al., 1987, 1988), but that these organisms can actually dominate the blooms.

During microscopic examination of the intestinal tract content of D. magna, we observed cyanobacterial cells (not shown) as well as traces of the $m c y$ gene cluster in the DNA and RNA of the zooplankton samples after PCR and quantitative PCR analyses (Table 2, Fig. 3). In contrast to Infante (1973) who found only a single case of cyanobacteria in the guts of zooplankton from the meso-eutrophic Lake Titisee in Germany, we observed Microcystis cells in the guts of 11 of the 50 D. magna specimens analyzed, but no cyanobacterial cells in Bosmina $s p$. The conflicting results that Daphnia could be feeding on toxic benthic Microcystis colonies in the natural environment may be explained by the assumption that toxicity varies according to the biochemical composition of the strains (Matveev et al., 1994) or to the fact that the contents of the intestinal tract of the daphnids analyzed were a mixture of phytoplankton which could have reduced the toxicity of the toxic Microcystis cells (Alva-Martinez et al., 2004). On the other hand, it could depend on the ability of a particular grazer to have different susceptibility to the toxin (DeMott et al., 1991). Holm and Shapiro (1984) reported that Aphanizomenon flos-aquae filaments when eaten by Daphnia pulex caused retarded growth, lower lipid index and suppressed reproduction. A mixture of Aphanizomenon and Scenedesmus resulted in equivalent growth to that with the green alga alone. 


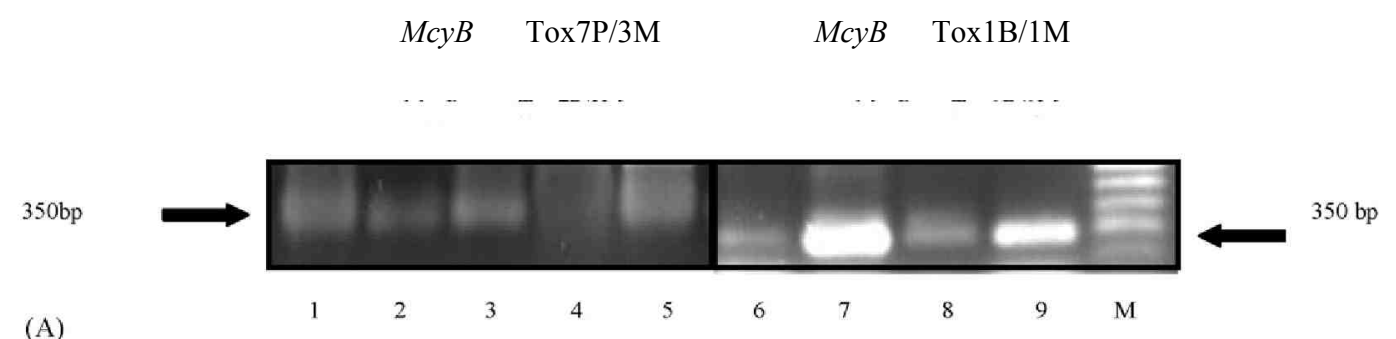

(A)

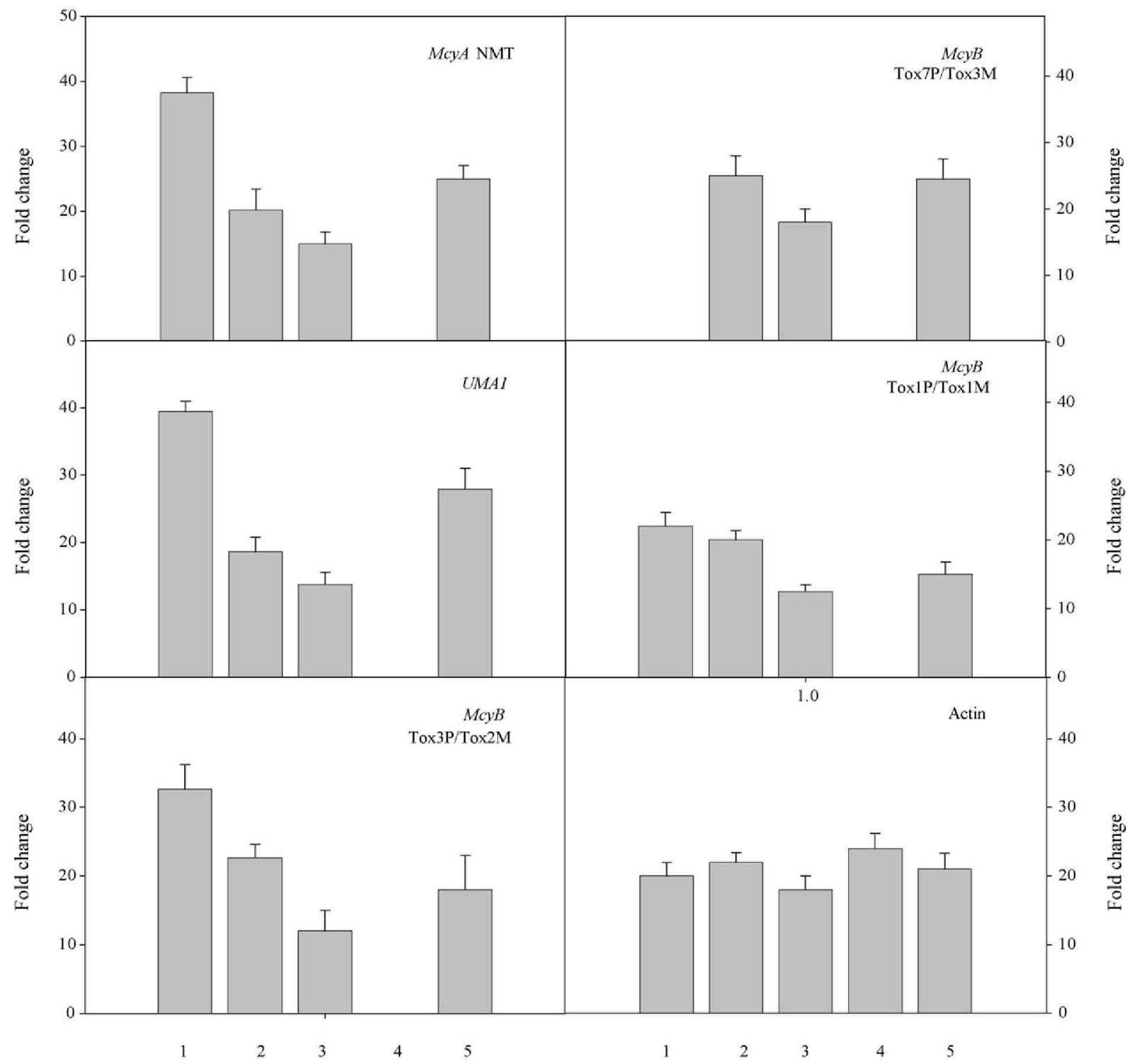

(B)

Fig. 3. (A) Separation of PCR amplicons obtained after PCR of Microcystis aeruginosa strain PCC7806 $(1,6)$ and M. aeruginosa strains sampled during August $(2,7)$ and November (3,8); Daphnia magna (laboratory population) (4); D. magna and Bosmina sp. (field sample) $(5,9)$ using primer set TOX7P/3M on a $2 \%$ agarose gel. (M) Hyperladder ${ }^{\mathrm{TM}}$ IV, Bioline, USA. (B) Quantitative PCR of RNA from M. aeruginosa strain PCC7806 (1) and M. aeruginosa strains sampled during August (2) and November (3); $D$. magna (laboratory population) (4); D. magna and Bosmina sp. (field sample) (5). Actin was included as standard. 
Table 2

Comparison of PCR with different primers, quantitative PCR, ELISA and protein phosphatase inhibition (PP2A) assay as determinants of toxicity in samples.

\begin{tabular}{|c|c|c|c|c|c|c|c|c|}
\hline \multirow[t]{2}{*}{ Organism } & \multicolumn{5}{|l|}{ PCR } & \multirow[t]{2}{*}{ RT-PCR $^{\text {a }}$} & \multirow[t]{2}{*}{ PP2A } & \multirow[t]{2}{*}{ ELISA } \\
\hline & $\begin{array}{l}\text { McyA- } \\
\text { MSR/MSF }\end{array}$ & $\begin{array}{l}\text { Umal- } \\
\mathrm{UMF} / \mathrm{R}\end{array}$ & $\begin{array}{l}M c y B- \\
\text { Tox3P/2M }\end{array}$ & $\begin{array}{l}M c y B- \\
\text { Tox1P/1M }\end{array}$ & $\begin{array}{l}M c y B- \\
\text { Tox1P/1M }\end{array}$ & & & \\
\hline $\begin{array}{l}\text { Mycrocytis aeruginosa } \\
\text { PCC7806 } \\
\text { (cultured strain) }\end{array}$ & + & + & + & + & - & + & + & + \\
\hline $\begin{array}{l}\text { M. aeruginosa } \\
\text { (field sample, summer) }\end{array}$ & + & + & + & + & + & + & + & + \\
\hline $\begin{array}{l}\text { M. aeruginosa } \\
\quad \text { (field sample, winter) }\end{array}$ & + & + & + & + & + & + & + & + \\
\hline Zooplankton & - & - & - & - & - & - & 1 & 1 \\
\hline $\begin{array}{l}\text { Zooplankton } \\
\text { (field sample) }\end{array}$ & + & + & + & + & + & + & I & / \\
\hline
\end{tabular}

+, Positive/product; -, negative/no product; /, not assayed.

${ }^{a}$ Primers used for RT-PCR in all samples are $M c y A$-MSR/MSF, Umal-UMF/R, $M c y B$ Tox3P/2M, $M c y B$ Tox1P/1M, $M c y B$ Tox $7 \mathrm{P} / 3 \mathrm{M}$.

Moina, usually co-occurring with Microcystis blooms in Lake Kasumigaura, showed suppressed growth and reproduction with Microcystis as the only food source, but the effect disappeared in 1:1 mixtures with Chlorella; the cyclopoid assimilated more Microcystis than Chlorella when the specimens were fed on an algal mixture (Hanazato and Yasuno, 1984; Alva-Martinez et al., 2004).

Most zooplankton is not affected by very large colonies of cyanobacteria. For example, blooms of large flakes of Aphanizomenon are often associated with high Daphnia densities (Ganf, 1983). Holm et al. (1983) considered 1.5 $\mathrm{mm}$ to be the maximum size of Aphanizomenon colonies that Daphnia pulicaria can handle, while large colonies $(>110 \mu \mathrm{m})$ of $M$. aeruginosa did not affect the filtering rate of Ceriodaphnia reticulata (O'Brien and DeNoyelles, 1974). Traces of the $m c y$ gene cluster in the guts of the zooplankton specimens indicate that $D$. magna ingest $M$. aeruginosa during winter when food sources are limited. Experimental work by Schoenberg and Carlson (1984) confirmed that $>20 \mu \mathrm{m}$ Microcystis colonies were grazed by Daphnia but were unaffected by Bosmina. However, it does not mean that the specific cyanobacterial gut cells are toxic, since non-toxic cultured strains may have fragments of microcystin synthetase genes or mutations within these genes. Amplicons can be amplified from these cultured strains with mcy primers, although they are not able to produce toxins (Dittmann et al., 2001; Kaebernick et al., 2001; Neilan et al., 1999; Tillett et al., 2001). It is thus suggested that the grazing of the Microcystis overwintering colonies may be in response to food limitation since phytoplankton was sparse and dominated by grazingresistant species during the sampling period (Fig. 2D). This does not, however, necessarily imply lower graze control of phytoplankton, as the growth rate of phytoplankton also decreases in winter (Fig. 2). Garnier and Mourelatos (1991) showed in a shallow lake in France that zooplankton consumption reduced phytoplankton production from 85 to $43 \%$, also suggesting a high grazing pressure during winter. The grazing on Microcystis cells in Sheldon Lake was probably done by the few daphnids observed in the samples and not Bosmina sp. The evidence from this and other studies for M. aeruginosa and the effects on zooplankton feeding behaviour are controversial, probably because different field strains may have different toxigenic properties (Baker et al., 2002; Kurmayer et al., 2002; Ouellette and Wilhelm, 2003).

\section{Acknowledgements}

The authors would like to express their sincere gratitude to the National Foundation of Research, and the Water Research Commission, South Africa for provision of funding.[SES] 


\section{References}

Alva-Martinez, A.F., Sarma, S.S.S., Nandini, S., 2004. Population growth of Daphnia pulex (cladocera) on a mixed diet (Microcystis aeruginosa with Chlorella or Scenedesmus). Crustaceana 77, 973-988.

An, J., Carmichael, W.W., 1994. Use of a colorimetric protein phosphatase inhibition assay and enzyme linked immunosorbent assay for the study of microcystins and nodularins. Toxicon 32, 1495-1507.

Anagnostidis, K., Komare'k, J., 1990. Modern approach to the classification system of cyanophytes. 1. Introduction. Arch. Hydrobiol. Algol. Stud. 38/39, 291-302.

Arnold, D.E., 1971. Ingestion, assimilation, survival and reproduction by Daphnia pulex fed seven species of blue-green algae. Limnol. Oceanogr. 16, 906-920.

Barbiero, R., Welch, E., 1992. Contribution of benthic blue-green algal recruitment to lake populations and phosphorous transloca-tion. Freshwater Biol. 27, 249-260.

Baker, J.A., Entsch, B., Neilan, B.A., McKay, D.B., 2002. Monitoring changing toxigenicity bloom by molecular methods. Appl. Environ. Microbiol. 68, 6070-6076.

Berthon, J.L., Brousse, S., 1995. Modification of migratory behaviour of planktonic crustacea in the presence of a bloom of Microcystis aeruginosa (cyanobacteria). Hydrobiologia 3000/301, 185-193.

Boström, B., Pettersson, A.K., Ahlgren, I., 1989. Seasonal dynamics of a Cyanobacteria-dominated microbial community in surface sediments of a shallow eutrophic lake. Aquat. Sci. 51, 153-178.

Carmichael, W.W., 1992. Cyanobacteria secondary metabolites: the cyanotoxins. J. Appl. Bacteriol. 72, 445-459.

Chomczynski, P., Mackey, K., Drews, R., Wilfinger, W., 1997. DNA-zol: a reagent for the rapid isolation of genomic DNA. Bio Techniques 22, $550-553$.

DeBernardi, R., Giussani, G., 1990. Are blue-green algae a suitable food for zooplankton? An overview. Hydrobiologia 200/201, 29-41.

DeBernardi, R., Giussani, G., Lasso Pedretti, E., 1981. The significance of blue-green algae as food for filter-feeding zooplankton: experimental studies on Daphnia spp. fed by Microcystis aeruginosa. Verhandlungen der internationalen Vereinigung für theoretische under angewandte Limnologie 21, 477-483.

DeMott, W., Zhang, Q.X., Carmichael, W.W., 1991. Effects of toxic cyanobacteria and purified toxins on the survival and feeding of a copepod and three species of Daphnia. Limnol. Oceanogr. 36, 1346-1357.

Dionisio Pires, L.M., Ibelings, B.W., Brehm, M., Van Donk, E., 2005. Comparing grazing on Lake Seston by Dreissena and Daphnia: lessons for biomanipulation. Microb. Ecol. 50, 242-252.

Dittman, E., Neilan, B.A., Erhard, M., von Do"hren, H., Bo"rner, T., 1997. Insertional mutagenesis of a peptide synthetase gene that is responsible for hepatotoxin production in the cyanobacterium Microcystis aeruginosa PCC7806. Mol. Microbiol. 26, 779-787.

Dittman, E., Neilan, B.A., Börner, T., 1999. Peptide synthetase genes occur in various species of cyanobacteria. In: Peschek, G.A., Loeffelhardt, W., Schemetterer, G. (Eds.), The Photo-trophic Prokaryotes. Kluwer Academic/Plenum, New York, pp. 615-621.

Dittmann, E., Erhard, M., Kaebernick, M., Scheler, C., Neilan, B.A., von Döhren, H., Börner, T., 2001. Altered expression of two light-dependent genes in a microcystin-lacking mutant of Microcystis aeruginosa PCC 7806. Microbiology 147, 3113-3119.

do Carmo Bittencourt-Oliveira, M., 2003. Detection of potential microcystin-producing cyanobacteria in Brazilian reservoirs with a $m c y B$ molecular marker. Harmful Algae 2, 51-60.

Dryden, R.C., Wright, S.J.L., 1987. Predation of cyanobacteria by protozoa. Can. J. Microbiol. 33, 471-482.

Failkowsak, E., Pajdak-Stos, A., 2002. Dependence of cyanobacteria defense mode on grazer pressure. Aquat. Microb. Ecol. $27,149-157$.

Fulton, R.S., Paerl, H.W., 1987. Toxic and inhibitory effects of the blue-green alga Microcystis aeruginosa on herbivorous zooplankton. J. Plank. Res. 9, 837-855.

Ganf, G., 1983. An ecological relationship between Aphanizomenon and Daphnia pulex. Aust. J. Mar. Freshwater Res. $34,755-773$.

Garnier, J., Mourelatos, S., 1991. Contribution of grazing in phyto-plankton overall losses in a shallow French lake. Freshwater Biol. 28, 515523.

Gilbert, J.J., 1990. Differential effects of Anabaena affinis on cladocerans and rotifers mechanisms and implications. Ecology 71, $1727-1740$.

Grobbelaar, J.U., 2005. Toxin production by Microcystis. Verh. Int. Verein. Limnol. 29, 631-634.

Grobbelaar, J.U., Botes, E., Van den Heever, J.A., Botha, A.M., Oberholster, P.J., 2004. Scope and dynamics of toxin produced by Cyanophytes in the freshwaters of South Africa and the implications for human and other users. WRC Report No: 1029/1/04, p. 9, ISBN: 1-77005-191-0

Hanazato, T., Yasuno, M., 1984. Growth, reproduction and assimilation of Moina macropoda fed on Microcystis and/or Chlorella. Jpn. J. Ecol. 34, $195-202$.

Haney, J.F., 1987. Field studies on zooplankton-cyanobacteria interactions. N. Z. J. Mar. Freshwater Res. 21, 467-475.

Hansson, L.-A., 1996. Behavioral response in plants: adjustment in algal recruitment induced by herbivores. Proc. R. Soc. Lond. B 263, 12411244.

Hansson, L.-A., 2000. Synergistic effects of food chain dynamics and induced behavioural responses in aquatic ecosystems. Ecology 81, 842-851.

Hawes, I., Howard, W.C., Vincent, W.F., 1992. Desiccation and recovery of Antartic cyanobacterial mats. Polar Biol. 12, 587-594.

Head, R.M., Jones, R.I., Bailey-Watts, A.E., 1999. An assessment of the influence of recruitment from the sediment on the development of planktonic populations of cyanobacteria in a temperate meso-trophic lake. Freshwater Biol. 41, 759-769.

Holm, N.P., Shapiro, J., 1984. An examination of the lipid reserves and the nutritional status of Daphnia pulex fed Aphanizomenon flos-aquae. Limnol. Oceanogr. 29, 1137-1140.

Holm, N.P., Ganf, G.G., Shapiro, J., 1983. Feeding and assimilation rates of Daphnia pulex fed Aphanizomenon flos-aquae. Limnol. Oceanogr. $28,677-687$. 
Howitt, C.A., 1996. Amplification of DNA from whole cells of cyanobacteria using PCR. Biotechniques 21, 32-33.

Huisman, J., Van Oostveen, P., Weissing, F.J., 1999. Species dynamics in phytoplankton biomes: incomplete mixing and competition for light. Am. Nat. $154,46-68$.

Ichimura, T., 1979. Media for blue-green algae. In: Nishizawa, K., Chihara, M. (Eds.), Methods in Algological Studies. Kyoritsu, Tokyo, pp. 294-305.

Ihle, T., Ja“hnichen, S., Benndorf, J., 2005. Wax and wane of Microcystis (Cyanophyceae) and microcytins in lake sediments: a case study in Quitzdorf reservoir (Germany). J. Phycol. 41, 479-488.

Inamori, Y., Hayashi, N.A., Sudoh, R., 1988. Experimental studies on the role of smaller animals with regard to the degradation of AOKO (waterbloom). Jpn. J. Water Treat. Biol. 24, 59-69.

Inamori, Y., Kumiyasu, Y., Ryuichi, S., 1987. Role of smaller metazoa in water purification and sludge reduction. Jpn. J. Water Treat. Biol. 23, 1523.

Infante, A., 1973. Untersuchungen uber die Ausnutzbarkeit verschied-ener Algen durch das Zooplankton. Arch. Hydrobiol. Suppl. 42 , $340-405$.

Jang, M.-H., Ha, K., Joo, G.-J., Takamura, N., 2003. Toxin production of cyanobacteria is increased by exposure to zooplankton. Freshwater Biol. 48, 1545-1550.

Jeppesen, E., Jensen, J.P., Sødergaard, M., Fenger-Grøn, M., Bramm, M.E., Sanby, K., Møller, P.H., Rasmussen, H.U., 2004. Impact of fish predation on cladoceran body weight distribution and zooplankton grazing in lakes during winter. Freshwater Biol. $49,432-447$.

Jochimsen, E.M., Carmichael, W.W., An, J., Cardo, D.M., Cookson, S.T., Holmes, C.E.M., Antunes, M.B.C., demelo Filho, D.A., Lyra, T.M., Barreto, V.S.T., Azevado, S.M.F.O., Jarvis, W.R., 1998. Liver failure and death after exposure to microcystins at a hemo-dialysis center in Brazil. N. Engl. J. Med. 338, 873-878.

Kaebernick, M., Rohrlack, T., Christoffersen, K., Neilan, B.A., 2001. A spontaneous mutant of microcystin biosynthesis: genetic characterization and effect on Daphnia. Environ. Microbiol. 3, 669-679.

Kalff, J., 2002. Limnology. Inland Water Ecosystems. Prentice-Hall, Inc., Upper Saddle River, NJ, 309-348.

Komárek, J., 1958. Die taxonomische Revision der planktischen Blaualgen der Tschechoslowakei. In: Algologische Studien, Aca-demia, Praha, pp. 10-206.

Kurmayer, R., Dittmann, E., Fastner, J., Chorus, I., 2002. Diversity of microcystin genes within a population of the toxic cyanobacterium Microcystis spp. in Lake Wannsee (Berlin, Germany). Microb. Ecol. 43, 107-118.

Lampert, W., 1981a. Inhibitory and toxic effects of blue-green algae on Daphnia. Rev. Ges. Hydrobiol. 66, $285-298$.

Lampert, W., 1981b. Toxicity of the blue-green Microcystis aeruginosa: effective defence mechanism against grazing pressure by Daphnia. Verh. Int. Verein. Limnol. 21, 1436-1440.

Lampert, W., 1987. Laboratory studies on zooplankton-cyanobacteria interactions. N. Z. J. Mar. Freshwater Res. 21, $483-490$.

Lampert, W., 1995. Egg bank investment. Nature 377, 479.

Lampert, W., Muck, P., 1985. Multiple aspects of food limitation in zooplankton communities: the Daphnia-Eudiaptomus example. Archiv für Hydrobiologie Beihefte Ergebnisse der Limnologie 21, 311-322.

Latour, D., Giraudet, H., Berthon, J.L., 2004. Frequency of dividing cells and viability of Microcystis aeruginosa in sediment of a eutrophic reservoir. Aquat. Microb. Ecol. 36, 117-122.

Lindholm, T., Eriksson, J.E., Reinikainen, M., Meriluoto, J.A.O., 1992. Ecological effects of hepatotoxic cyanobacteria. Environ. Toxicol. Water Qual. 7, 87-93.

Matveev, V.F., Balseiro, E.G., 1990. Contrasting responses of two cladocerans to changes in the nutritional value of nanoplankton. Freshwater Biol. 23, 197-204.

Matveev, V., Matveeva, L., Jones, G.J., 1994. Study of the ability of Daphnia carinata King to control phytoplankton and resist cya-nobacterial toxicity: implications for biomanipulation in Australia. Aust. J. Mar. Freshwater Res. 45, 889-904.

May, V., 1981. The occurrence of toxic cyanophyte blooms in Australia. In: Carmichael, W.W. (Ed.), The Water Environment. Algal Toxins and Health. Plenum Press, New York, pp. 26-28.

Mills, D.H., Wyatt, J.T., 1974. Ostracod reactions to non-toxic and toxic algae. Oecologia 17, 171-177.

Needham, J.G., Needham, P.R., 1962. A Guide to the Study of Freshwater Biology, 5th ed. Holden-day, Inc., San Francisco, pp. 18-28.

Neilan, B.A., Dittmann, E., Rouhiainen, L., Bass, A., Schaub, V., Sivonen, K., Börner, T., 1999. Non-ribosomal peptide synthesis and toxigenicity of cyanobacteria. J. Bacteriol. 181, 4089-4097.

O’Brien, W.J., DeNoyelles Jr., F.H., 1974. Filtering rate of Cerio-daphnia reticulata in pond waters of varying phytoplankton concentrations. Am. Midland Nat. 91, 509-512.

Olrik, K., 1994. Phytoplankton Ecology. Miljøprojekt 251. Danish Environmental Protection Agency, Copenhagen, p. 183.

Ostrofsky, M.L., Jacobs, F.G., Rowan, J., 1983. Evidence for the production of extracellular herbivore deterrents by Anabaena flos-aquae. Freshwater Biol. 13, 501-506.

Ouahid, Y., Perez-Silva, G., del Campo, F.F., 2005. Identification of potentially toxic environmental Microcystis by individual and multiple PCR amplification of specific microcystin synthetase gene regions. Environ. Toxicol. 20, 235-242.

Ouellette, A.J.A., Wilhelm, S.W., 2003. Toxic cyanobacteria: the evolving molecular toolbox. Ecol. Environ. 1, 359-366.

Porra, R.J., Thompson, W.A., Kriedemann, P.E., 1989. Determination of accurate extinction coefficients and simultaneous equations for assaying chlorophylls $a$ and $b$ extracted with four different solvents: vertification of the concentration of chlorophyll standards by atomic absorption spectrometry. Acta Biochim. Biophys. 975, 348-394.

Reynolds, C.S., 1984. The Ecology of Freshwater Phytoplankton. Cambridge University Press, Cambridge.

Reynolds, C.S., 1987. Cyanobacterial water-blooms. Adv. Bot. Res. 13, 67-143.

Reynolds, C.S., 1988. Functional morphology and adaptive strategies of freshwater phytoplankton. In: Sandgren, C.D. (Ed.), Growth and Reproductive Strategies of Freshwater Phytoplankton. Cambridge University Press, Cambridge, pp. 388-433.

Reynolds, C.S., Walsby, A.E., 1975. Water-blooms. Biol. Rev. 50, 437-481.

Reynolds, C.S., Rogers, D.A., 1976. Seasonal variations in the vertical distribution and buoyancy of Microcystis aeruginosa Kütz. emend. Elenkin. 
Rosetherne Mere Eng. Hydrobiol. 48 (1), 17-23.

Reynolds, C.S., Jaworski, G.H.M., Cmiech, H.A., Leedale, G.F., 1981. On the annual cycle of the blue-green alga Microcystis aeruginosa Kütz. emend. Elenkin. Phil. Trans. Roy. Soc. Lond. Biol. Sci. 293, 419-477.

Richman, S., Dodson, S.I., 1983. The effect of food quality on feeding and respiration by Daphnia and Diaptomus. Limnol. Oceanogr. 28, 948956.

Rohrlack, T., Christoffersen, K., Dittman, E., Nogueira, I., Vasconce-los, V., Börner, T., 2005. Ingestion of microcystins by Daphnia: intestinal uptake and toxic effects. Limnol. Oceanogr. 50, 440- 448.

Schindler, D.W., 1969. Two useful devices for vertical plankton and water sampling. Can. F. Fish Res. Bd. 26, 1948-1955.

Schoenberg, S.A., Carlson, R.E., 1984. Direct and indirect effects of zooplankton grazing on phytoplankton in a hypertrophic lake. Oikos 42 , 291-302.

Sheldon Lake Drainage Improvement Project, 2002. Newsletter, no. 1, September, pp. 1-4 (http://www.fcgov.com/stormwater/sheldon-lake.hlm).

Sheldon Lake Drainage Improvement Project, 2003a. Newsletter, no. 2, January, p. 1 (http://www.fcgov.com/stormwater/sheldonlake.hlm).

Sheldon Lake Drainage Improvement Project, 2003b. Newsletter, no. 3, June, pp. 1-2 (http://www.fcgov.com/stormwater/sheldonlake.hlm).

Silva, W.M., Matsumura-Tundisi, T., 2005. DNA extraction and ITS2 (internal transcribed spacer 2) gene sequences of some Brazilian freshwater copepods. Verh. Int. Verein. Limnol. 29, 409-413.

Smith, G.M., 1950. Fresh Water Algae of the United State of America, 2nd ed. McGraw-Hill, New York, pp. 1-719.

SYSTAT, 1997. Systat ${ }^{\circledR} 7.0 .1$ for Windows ${ }^{\circledR}:$ Statistics. SPSS Inc., City, USA.

Tillett, D., Dittman, E., Erhard, M., von Döhren, H., Börner, T., Neilan, B.A., 2000. Structural organization of microcystin biosynthesis in Microcystis aeruginosa PCC 7806 an integrated peptide polyketide synthetase system. Chem. Biol. 7, 253-264.

Tillett, D., Parker, D.L., Neilan, B.A., 2001. Detection of toxigeni-city by a probe for the microcystin synthetase A gene $(m c y A)$ of the cyanobacterial genus Microcystis: comparison of toxicities with 16S rRNA and phycocyanin operon (phycocyanin inter-genic spacer) phylogenies. Appl. Environ. Microbiol. 67, 2810-2818.

Trabeau, M., Bruhn-Keup, R., McDermott, C., Keomany, M., Millsaps, A., Emery, A., De Stasio, B., 2004. Midsummer decline of a Daphnia population attributed in part to cyanobacterial capsule production. J. Plankton Res. 26, 949-961.

Ueno, Y., Nagata, S., Tsutsumi, T., Hasegawa, A., Yoshida, F., Suttajit, M., Mebs, D., Putsch, M., Vasconcelos, V., 1996. Survey of microcystins in environmental water by a highly sensitive immunoassay based on monoclonal antibody. Nat. Toxins 4, 271-276.

Utkilen, H., Gjolme, N., 1995. Iron-stimulated toxin production in Microcystis aeruginosa. Appl. Environ. Microbiol. 61, 797- 800.

Vasconcelos, V.M., 1990. Preliminary results of a study on the impact of toxic and nontoxic cyanobacteria on some freshwater micro-crustacean species. Crustaceana 59, 316-318.

Verspagen, J.M.H., Snelder, E.O.F.M., Visser, P.M., Huisman, J., Mur, L.R., Ibelings, B.W., 2004. Recruitment of benthic Microcystis (Cyanophyceae) to the water column: internal buoyancy changes or resuspension? J. Phycol. 40, 260-270.

Verspagen, J.M.H., Snelder, E.O.F.M., Visser, P.M., Jo“hnk, K.D., Ibelings, B.W., Mur, L.R., Huisman, J., 2005. Benthic-pelagic coupling in the population dynamics of the harmful cyanobacterium Microcystis. Freshwater Biol. 50, 854-867.

Wetzel, R.G., 1983. Limnology, 2nd ed. Sanders Coll. Publ., Phili-delphia.

Zhang, Z.-G., Bai, G., Deans-Zirattu, S., Browner, M.F., Lee, E.Y.C., 1992. Expression of the catalytic subunit of phosphorylase phosphatase (protein phosphatase-1) in Escherichia coli. J. Boil. Chem. 267, 1484-1490. 